details of these transmissions can be obtained on application to the Director, National Physical Laboratory, Teddington, Middlesex.

\section{Lead Sheaths of Electric Cables}

LEAD is a very suitable metal for providing a watertight covering to an electric cable buried in the earth. The weight of the lead sheaths made per annum in Britain alone is 64,000 tons. Taking into account the much larger quantity that must be used in the many cable factories throughout the world, it will be seen that an improvement in the technique of the manufacture of lead sheaths is one which seriously concerns both users and manufacturers. Of recent years, much thought has been given to this problem and very many patents have been taken out for improvements. In a paper by Dr. P. Dunsheath, read to the Institution of Electrical Engineers on December 3, a method for the continuous extrusion of lead sheaths over cables is described which is being widely adopted by manufacturers. Hitherto, the extrusion of the lead has been done by the ram of a hydraulic press. In Dr. Dunsheath's mothod, the pressure required to extrude the lead is obtained by means of a motor-driven screw member. In 1929 the first lead pipe was extruded by a continuous process, and the development has continued steadily up to the present. A defect of cable sheaths made on hydraulic presses is the inclusion in the finished pipe of welds between separate faces of metal, which at some stage in the process have been exposed to the air and therefore become slightly oxidized. Provided sufficient time is allowed to elapse and sufficient pressure applied at a sufficiently high temperature, two separate masses of lead will weld together com. pletely into one homogeneous mass if the faces are clean and free from oxide.

\section{Air Raid Precautions and Air Disarmament}

A PAMPHLET entitled "Defence that is no Defence", by Dr. C. E. M. Joad, issued by the National Peace Council, directing attention to the inadequacy of the Government proposals for defence against air raids and the impossibility of devising any adequate protection against simultaneous attack by gas, explosive and incendiary bombs, quotes the warning against this barbarous perversion of science and industry in the tendency to accept the use of aircraft for unrestricted bomb and gas attack on civilized populations uttered by leading scientific workers when the Government schemes were first introduced. Subsequent events have only confirmed the prediction that acceptance of this position must rapidly lead to the breakdown of civilized life. Dr. Joad, while emphasizing the futility of the measures so far proposed by the Government and also the difficulty of its position, urges that the Government should work strenuously for abolition of the bombing aeroplane and for disarming in the air and placing civil aviation on an international basis, as affording the only security against destruction of our cities by attack from the air. He also urges a policy directed towards the removal of economic tensions which are endangering peace, and suggests a definite lead from Great Britain in regard to access to raw materials and equalizing of opportunities for trade which might be provided by an extension of the mandates system, the lowering of tariffs and removal of economic barriers.

\section{Scientific Management and Economic Problems}

IN an address to the Engineers' Study Group on Economics on January 19, Major L. R. Urwick spoke on the contribution of scientific management to the solution of present economic difficulties. He outlined the development of the principles of scientific management from the pioneer work of Charles Babbage and E. W. Taylor to such recent manifestations as "Stakhanovism" in Russia. Scientific management means essentially not the multiplication of efficiency experts but the adoption by both employers and employed of a new mental outlook, based on exact measurement and not on opinion, and more interested in increasing the output of industry than in haggling about its division. Resistance to Taylor's ideas had largely been due to those of his followers who had adopted his methods piecemeal while neglecting the underlying philosophy. Scientific management has spread much faster on the productive side of industry than on the distributive, or in finance, and the machinery of Government has also profited far less than it should have from the available knowledge of management problems. The first part of a chapter on "The Division of Labour and the Pricing System" has recently been forwarded in draft, and the chapter on "Money and Banking" has been discussed at a recent meeting of this Group.

\section{Analytical Control of Foods and Drugs}

Extracts from the annual report of the Ministry of Health and abstracts of reports of public analysts upon the analytical control of foods and drugs for 1935 have been issued as a separate pamphlet (Sale of Foods and Drugs. H.M. Stationery Office, 1936. $3 d$. net). No less than 143,831 samples were analysed by public analysts in England and Wales, of which 7,972 , or $5 \cdot 5$ per cent, were reported against. The number of samples of milk examined was 78,674, of which 5,798 samples were reported to be adulterated or not up to standard. Several samples of canned products were found to be contaminated with tin, lead, copper or zinc. A few samples of sugar contained sand, and one of icing sugar rancid fat and dead flies. Adverse reports were made on a number of 'cream' cakes and pastries on the ground that the filling consisted wholly or partially of fat other than milk fat, and a number of 'chocolate' rolls and cakes contained no chocolate. The reports of the public analysts are abstracted in a series of tables.

\section{National Institute for Research in Dairying, Reading}

IN the annual report for 1935 of this Institute, which has recently been issued, the research and other activities are summarized. The research work includes such varied subjects as winter feeding of young dairy cattle and artificial insemination of 
cows, investigations on the chemical composition of typical milk and of taints of milk, the lactic acid bacteria and cheese-ripening studies, and on pasteurization and tubercle bacilli in milk. Cases of contagious abortion among the Institute's herd of cows gave an opportunity for investigating Brucella abortus infection. Bacteriological testing of milk samples and market milk investigations have also been carried out, and the phosphatase test for efficiency of pasteurization has been re-examined. The financial condition of the Institute is considered, and an appeal is made for further funds to enable an extension of the work to be made.

\section{Oxford and Present Needs in Science}

Referring to the leading article in NATure of February 20 under this title, a correspondent writes as follows: "As some readers may not be familiar with the names given to certain buildings in Oxford, it may be helpful to state that the 'Ashmolean Museum' now means the Museum of Art and Archæology, chiefly classical, established in Beaumont Street in 1890, whereas the 'Museum of the History of Science' means the ancient scientific collections in the Old Ashmolean Building, which was the only science museum from 1683 until 1860. In this building Ashmole's old museum room is now full to overflowing of historic instruments and specimens; and money is needed for its extension. The changes contemplated in the various scientific departments of the University make it more than ever necessary to provide for the preservation of things of historic value that might otherwise be scrapped".

\section{Early Man in Minnesota}

Prof. A. E. Jenks, of the University of Minnesota, reporting recently on "Minnesota man", a female skeleton found in ancient lake deposits in 1931, attributes to it an age of approximately 20,000 years, and regards it as the oldest specimen of early man to be found in America. The teeth had all erupted, with the exception of the wisdom teeth, but as the long bones appear to be still immature, the age of the girl was probably about fifteen years. The teeth are larger than normal in prehistoric man. In summing up the characters of the skeleton, Prof. Jenks, it is stated by Science Service, regards it as Homo sapiens, of an early type of evolving Mongoloid, forecasting the aboriginal American, especially the Eskimo, rather than the modern Mongol. It has been computed that the Lake Pelican deposits, in which the skeletal remains were found, antedata those of the glacial Lake Agasiz by some two thousand years, thus warranting this increase in the age usually admitted for early man on the American continent.

\section{Sanitary Aviation in Soviet Russia}

THE sanitary aviation service maintained by the Red Cross and Red Crescent Society of the U.S.S.R. is fast becoming a regular institution for medical aid, particularly in outlying regions of the Union. Sanitary aeroplanes are kept in readiness in all parts of the Union to answer urgent calls for medical aid. In
1936, more than 400 patients were carried by air to hospitals and more than 500 specialists were taken by air to various places where they performed some fifty major operations and treated about four thousand seriously ill persons. In 1936 also, the sanitary aeroplanes of the Red Cross and Red Crescent Society carried more than 2,000 kilograms of medical supplies to different points of the Union.

\section{Biochemistry in the U.S.S.R.}

WE have received the first five numbers of the first volume of a new Russian journal, devoted to biochemistry. It is entitled Biochimia, and is edited by A. N. Bach and W. A. Engelhardt. The papers are in Russian, but each is provided with a summary in English or German. The average size of each number is about 120 pages. The papers deal with work on vitamins, enzymes and other biochemical problems. The journal should enable workers in other countries to gain some idea of the work which is being carried out in Russia in biochemistry.

\section{Comets}

A New comet was discovered by Dr. F. L. Whipple at Harvard on February 7 . Its magnitude was 12 at the time of discovery, and it was described as diffuse with a central condensation, and a tail less than $1^{\circ}$ in length. Dr. Whipple computed the following parabolic orbit :

$$
\begin{array}{crr|r}
T 1937 & \text { Jan. } & 22 \cdot 070 & \text { U.T. } \\
\omega & 111^{\circ} & 27^{\prime} & \\
\Omega & 127 & 4 & 1937 \cdot 0 \\
i & 41 & 4 & \\
q & 1 \cdot 6610 & &
\end{array}
$$

It is now about 1.5 units from the earth, which it is approaching, but it is not likely to become a con. spicuous object. Mr. Simizi in Japan detected Daniel's Comet, $1909 \mathrm{iv}, 1937 a$, on January 31. Its magnitude was 13 and it was diffuse without any central condensation. Mr. Hirose computed an orbit the elements of which are given below. It is receding from the earth, and is now more than 1.4 units distant.

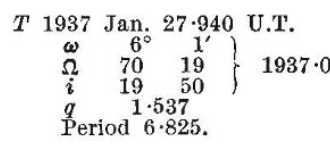

\section{The Night Sky in March}

During March, the duration of night in the latitude of London decreases by nearly two hours. On March $21^{\mathrm{d}} 1^{\mathrm{h}}$ the sun enters the sign Aries (Spring Equinox). The moon is new on March $12^{\mathrm{d}} 19 \cdot 5^{\mathrm{h}}$ and full on March $26^{\mathrm{d}} 23 \cdot 2^{\mathrm{h}}$. No bright stars are occulted during the month, but the following disappearances may be noted : 108 Tauri (mag. $6 \cdot 2$ ) on March $18^{\mathrm{d}} 19^{\mathrm{h}} 39 \cdot 0^{\mathrm{m}}$ when the moon is 6 days old, and $e$ Leonis (mag. $5 \cdot 1$ ) on March $25^{\mathrm{d}} 21^{\mathrm{h}} 54 \cdot 4^{\mathrm{m}}$, the moon being 13 days old. The planet Venus, which does not set until about $22^{\mathrm{h}}$, is a striking object and reaches its greatest brilliancy on March 12; the area of the illuminated crescent is then $0 \cdot 28$ that of the whole apparent disk. Mercury, being in superior conjunction with the sun 